\title{
SOCIAL REINTEGRATION OF CRACK ADDICTS: ACTIONS TAKEN BY THE FAMILY
}

\author{
Daiana Foggiato de Siqueiraㄹ, Dirce Stein Backes², Claudete Moreschi ${ }^{3}$, Marlene Gomes Terra ${ }^{4}$, Keity Laís \\ Siepmann Soccol ${ }^{5}$, Valquíria Toledo Souto ${ }^{6}$
}

\footnotetext{
${ }^{1}$ Doctoral student of the Nursing Graduate Program (PPGenf) of the Universidade Federal de Santa Maria (UFSM). Santa Maria, Rio Grande do Sul, Brazil. E-mail: daianasiqueira@yahoo.com.br

2 Ph.D. in Nursing. Professor of the Graduate Course in Nursing of the Centro Universitário Franciscano. Santa Maria, Rio Grande do Sul, Brazil. E-mail: backesdirce@ig.com.br

${ }^{3}$ Doctoral student in Environment and Development at the Centro Universitário UNIVATES. Scholar of the Rio Grande do Sul Research Foundation. Lageado, Rio Grande do Sul, Brazil. E-mail: clau_moreschi@yahoo.com.br

${ }^{4}$ Ph.D. in Nursing. Professor of the Nursing Department of UFSM. Santa Maria, Rio Grande do Sul, Brazil. E-mail: martesm@ hotmail.com.br

${ }^{5}$ Doctoral student of PPGEnf/UFSM. Santa Maria, Rio Grande do Sul, Brazil. E-mail: keitylais@hotmail.com

${ }^{6}$ Master's student of PPGEnf/UFSM. Santa Maria, Rio Grande do Sul, Brazil. E-mail: valquiriatoledo@hotmail.com
}

ABSTRACT: The aim of this study was to understand the perception of families about the actions developed by them in the search for social reintegration of their crack addict relative. This is a qualitative study conducted with 10 family members of crack-addicted individuals who were hospitalized in a detoxification treatment unit of psychoactive substances. Data were collected in April and May 2011, through the focus group technique and categorization was based on content analysis. Family members contribute significantly to the social reintegration of their relative, they feel co-responsible for their treatment, and therefore they guide them in the search for a new path. Families play an essential role in the life of drug-addicted relatives and are aware that they must be present in the relative's life, constantly seeking strategies to help them and support them in coping with their suffering and treatment.

DESCRIPTORS: Family. Crack cocaine. Street drugs. Adolescent.

\section{REINSERÇÃO SOCIAL DO INDIVÍDUO DEPENDENTE DE CRACK: AÇÕES DESENVOLVIDAS PELA FAMÍLIA}

RESUMO: O presente estudo teve como objetivo conhecer a percepção do familiar acerca das ações desenvolvidas pela família em busca da reinserção social do seu familiar dependente de crack. Pesquisa qualitativa realizada com 10 familiares de indivíduos dependentes de crack internados em uma unidade de tratamento de desintoxicação de substâncias psicoativas. Os dados foram coletados nos meses de abril e maio de 2011, por meio da técnica de grupo focal e a categorização ocorreu com base na Análise de Conteúdo. Os membros da família contribuem significativamente para a reinserção social do seu familiar dependente de crack e sentem-se corresponsáveis pelo seu tratamento e, por isso, orientam que ele busque um novo caminho. A família possui um papel preponderante na vida do familiar dependente de crack e percebe que precisa estar presente na vida dele, buscando constantemente estratégias para ajudá-lo e apoiá-lo no enfrentamento do seu sofrimento e no seu tratamento.

DESCRITORES: Família. Cocaína crack. Drogas ilícitas. Adolescente.

\section{REINSERCIÓN SOCIAL DE LA PERSONA DEPENDIENTE DE CRACK: ACCIONES DESARROLLADAS POR LA FAMILIA}

RESUMEN: El objetivo de este estudio es estudiar la percepción de la familia acerca de sus medidas tomadas en busca de la reinserción social de su familiar dependiente de crack. Investigación cualitativa realizada con 10 miembros de la familia de los individuos dependientes de crack ingresados en un planta de tratamiento de desintoxicación de sustancias psicoactivas. Los datos fueron recolectados en abril y mayo de 2011, través de la técnica de grupo focal y la categorización se basó en el análisis de contenido. Los familiares contribuyen significativamente a la reinserción social de su familiar, se sienten co-responsables por su tratamiento y orientan para que el busqué un nuevo camino. La familia tiene un papel importante en la vida del dependiente de crack y se da cuenta de que debe estar presente en su vida, en constante búsqueda de estrategias para ayudarle y apoyarle en hacer frente a su sufrimiento y de su tratamiento. DESCRIPTORES: Familia. Cocaina crack. Drogas ilícitas. Adolescente. 


\section{INTRODUCTION}

The use of drugs is an old practice in human history, which has remained in different societies, and has been associated with sociocultural traditions, religious and mystic rituals, and has even been considered as a facilitator of social interaction. ${ }^{1}$ However, the relationship between men and drugs has changed over time, and the use of drugs in Brazil can be currently considered as a problem that has been challenging public policies, the routine of services and family and social relations in many ways. ${ }^{2}$

Among these challenges, there is the need to promote social reintegration of drug-addicted individuals. Social reintegration is associated with the possibility of reestablishing ties and coexistence between the individual and relatives and other members of society, by means of movement and occupation of social spaces. ${ }^{3}$ The social reintegration of the drug addict is a strategy that needs to be driven by mental health professionals, by means of actions that allow this individual to have more autonomy and power to continue treatment. However, this process must be put in place together with the family. ${ }^{3}$

Family is considered as the main socializing institution for the individual. It plays an important role both in creating conditions that imply in drug addiction and in creating a safety network for its members. ${ }^{2}$ The influence the family is under and it has on members who develop drug addiction was pointed out in some studies as a generator of great impact on the family daily life, especially when it comes to families of crack addicts, as this drug stimulates the central nervous system and is increasingly widespread, a fact that is frightening society. ${ }^{4-7}$

Considering the need for further reflection on the influence of families on their members, and highlighting the importance of analyzing and questioning strategies implemented by the family to socially reintegrate the crack-addicted individual, it is necessary to start from the relatives' point of view. Understanding the perception of relatives also becomes relevant because most existing scientific publications on the topic have as their object of study health professionals or health institutions that give support to crack addicts. ${ }^{1,-5}$

In view of the above, the following question is raised: What are the actions developed by the family in the pursuit of social reintegration of their crack-addicted relative? The objective was to understand the perception of relatives on the actions taken by their family in the search for social reintegration of their crack-addicted relative.

\section{METHOD}

This is an exploratory and descriptive study with a qualitative approach. The setting was a treatment unit for detoxification of psychoactive substances of a medium-sized hospital, located in the central area of the state of Rio Grande do Sul, designed for treatment of crack users (adolescents between 14 and 18 years old), who remain hospitalized for periods that vary from 9 to 12 weeks. The following inclusion criteria were adopted for the participation of relatives in the study: being a relative of a crack user who is in process of detoxification and being a resident of the municipality where the study was carried out. After a formal invitation, ten relatives (parents and grandparents, aged between 30 and 60 years) made themselves available to participate in the study and signed a Terms of Free and Informed Consent.

Data were collected between April and May 2011, in a private room, by means of the focus group technique, based on the discussion between participants, so as to analyze different opinions, attitudes and perceptions on a specific topic, fact or practice through interaction within the group. ${ }^{8}$ To do so, the four meetings performed with relatives of the focus group were recorded on digital media, and subsequently transcribed. The main researcher acted as a coordinator (moderator) and a nurse acted as an observer. The notes taken by the observer during the group sessions were also analyzed.

Data were analyzed by means of categorization, based on content analysis, ${ }^{9}$ which occurred in three steps: first, in a frequency with the identification of the main perceptions of participants of the focus group; second, in the content analysis that identified the categories that emerged from data collected; and third, the interpretation of the categories.

The study was submitted to ethical procedures recommended by Resolution 196/96 of the Health Council of Brazil, ${ }^{10}$ and was approved by the Research Ethics Committee under protocol number 279.2009.02. In order to ensure anonymity, participants were identified throughout the text by the letter $\mathrm{R}$ (for relative), followed by a number. 


\section{RESULTS AND DISCUSSION}

The content that emerged from the statements was analyzed and divided into two theme categories: taking co-responsibility and leading to a new path.

\section{Taking co-responsibility}

Being a relative of a crack addict means being involved in a context of challenge that requires permanent responsibility and actions that aim to keep the drug user close to the family and away from problems brought by drug addiction. Actions taken by relatives are expressed in the form of support and attention to their crack-addicted relative. They occur when relatives feel co-responsible for treatment, so they pay a visit during hospitalization, give advice, and look for services or institutions that may help social reintegration after discharge.

I'm giving support, I come to visit her [crackaddicted daughter], give advice, and also, I'm already looking for a church, even though she is still here. It's a start! (R7).

Family support, found in the statement above, is explicit in the presence alongside the drug user during hospitalization and in the search for help, by means of religious practice. This factor is in line with the idea that facing problems related to crack presupposes the integration of other resources in addition to those of health, such as social, psychological, economic, safety, and also, religious resources. ${ }^{2}$ Religious support is an important strategy in the pursuit of comfort and hope for human beings, especially when they face illness or traumatic situations. Furthermore, religious practices help to prevent self-destructive behavior, such as those expressed after the abuse of chemical substances. ${ }^{11}$

In that sense, the acknowledgment by relatives that the search for religious support contributes to the reintegration of crack-addicted individuals reaffirms the need for nursing professionals to understand religious practices and the singularity of each patient, so as to strengthen "their mechanisms to face the problem and help them empower practices that promote health". 11:1258 In addition, it reaffirms to relatives the power of these mechanisms as a strategy for social reintegration.

Another strategy employed by relatives as a contribution to social reintegration of the individual was to find a way of keeping them busy, either by sending them back to school or by entering the labor market.

The solution for my daughter is to be busy, to go back to school. I will look for a job for her, I know it's not going to be easy, because a lot of people don't accept former drug addicts (R3).

In the statement above, the relative also points out to a barrier to be overcome in the search for social reintegration of users: discrimination. It is a "different and often unequal treatment of people, formally or informally grouped in a particular category". ${ }^{12: 1182}$ Regarding drug users, once they are labeled as drug addicts, they may be discriminated in the labor market, even having their civil rights hampered.

This setting of discrimination and prejudice in which crack addicts are inserted affects their relatives directly, who may feel overburdened. Over time, a helpless and discouraged attitude of relatives seems inevitable, as a result of the difficulty encountered by the family in its reorganization after periods of crisis, since a lot of efforts are made and poor results are obtained. ${ }^{5}$

Although family members show signs of weariness and discouragement, they keep supporting the drug-addicted relative, hoping for rehabilitation and social reintegration. Some relatives believe that direct or indirect support provided to users is what the family can do at admission, but rehabilitation and reintegration after discharge is conditioned on efforts made by users themselves during treatment.

[...] everyone in here has the support of their parents, and that's what we can do. Now it's up to them (R7).

[...] (R1).

[...] I will help her, taking care of her children

It is understood that family support is very important, especially during treatment. A study showed that users who maintain family ties during hospitalization obtain better results than those who have no ties with their families. ${ }^{13}$ However, this role is not easy to play, as families can experience different feelings in this situation, such as guilt, outrage, prejudice and helplessness after finding out about the use of drugs or relapse of the drug addict. ${ }^{14}$

Changes in family relationships that result from the coexistence with drug users can be seen as a harmful situation, and also as a concrete possibility of affecting the health of other family members. The concerned family ends up getting a certain 
amount of problems that are part of routine, and they are intimidated by fear, violence, feelings of resignation and concern that other family members become users. ${ }^{2}$ In that sense, it is necessary to include families in health services and practices in order to meet the different demands of the family universe. $^{2}$

For the family to take co-responsibility in the care of crack users, it is essential to have support from nursing. In their professional practice, nurses can provide the adequate support for them to overcome situations of physical, emotional, mental and psychological weariness, by embracing, listening and guiding families. When families feel they are being supported, they become more involved and co-responsible for the care service. ${ }^{15}$

Moreover, throughout discussions, various actions developed by relatives were seen in the pursuit of a new path for the drug addict in question, which will be addressed in the next category.

\section{Leading to a new path}

The actions developed by relatives to contribute to users' reintegration are driven by the hope that they rebuild their lives away from drugs. Relatives believe that after hospital discharge, changes in attitude are necessary in regards of crack, in the search for a new way, of happiness and spiritual peace.

[...] I'm supporting her, giving advice, for when she leaves this place towards happiness (R2).

[...] after she leaves here, I want her to continue in the right direction, in the path of God (R7).

The feeling of emptiness, loneliness, the absence of people who understand the devastating effects of crack in users' lives result in an incomparable suffering and in a life story built from unlawful grounds, thus preventing the possibility of personal, family and occupational restructuring. In relatives' perception, the correct path to be followed in life that allows to find happiness cannot be linked to crack use. In that sense, relatives hope that the user manages to continue treatment after discharge and overcomes barriers that would change their trajectory, such as relapse.

Relapse can be avoided not only with medication but also with users' willpower and continuous support from family in the search for strategies that help this rehabilitation process. ${ }^{5}$ Among these strategies, the search for support in religion seems to provide an environment that is favorable to establish new emotional ties with other individuals within the community, which makes it possible to find a new meaning and new priorities for life, since it is known that spirituality is related to the essence of life and develops new behaviors and feelings of love and hope. ${ }^{16-17}$

In addition to this, there is the development of strategies such as mutual help groups, awareness workshops to face drugs and active participation of community centers, which can help users review their relationship with drugs. ${ }^{2}$

I hope that from now on my daughter and I start over again, because crack takes everything away, literally everything. A general reconstruction has to be made. Someone who has a drug addict at home lives through a sort of tsunami. It doesn't destroy houses, but it's almost the same (R5).

Perception of crack as a devastating drug, as evidenced in the statement above and which is disseminated as such in society, brings out feelings of failure, in such a way that the relationship with the crack-addicted relative needs a fresh start. The leading role crack can play interferes in sentimental, fraternal and family relationships, leaving negative consequences in the lives of those who live with and follow the drug user. Family, friends and other people involved cannot stand the routine experienced after crack enters into their lives. The absence of a true and significant existential meaning contributes to hamper respect, trust and credibility that they had before drug addiction. ${ }^{4}$

However, living with drug users does not weaken the potential of each family member, then nursing professionals may identify and mobilize them to work in the promotion of family health. ${ }^{18}$ To do so, professionals can look for a multidisciplinary supporting network that takes co-responsibility together with the family in order to reintegrate the user to society. Besides support given during hospitalization, relatives pointed out to the need to take users away from any possible negative influence that could compromise their shift away from drugs.

First of all, after she leaves here, I'll have to keep her away from her friends (R4).

Keep her away from her boyfriend, and always try to know where she is [...] (R9).

[...] I might be wrong, but if I don't keep her away from him [boyfriend] and her friends, she will come back (R10).

Initiation in drug consumption is associated with the search for respect, acceptance, social access and pressure, as well as the desire to be part 
of a group..$^{19}$ This is in line with a study conducted in 14 state capitals of Brazil, regarding the use of illicit drugs by teenagers, which points out at family issues, influence of friends, group pressure, search for pleasure, personal conflicts and naivety. ${ }^{20}$

Separation from people who could influence the use of crack and the maintenance of constant watch over the user were strategies used by relatives. The literature acknowledges that it is necessary to rely on an effective social support network, built by relevant people who play a role of safe reference to those who are exposed to adversity, in order to sustain positive responses in adverse situations, such as the addiction to this substance. ${ }^{18}$

From that point of view, relatives play their role being supported by care provided by health professionals. Embracement and listening are essential strategies that need to be carried out by the nurse and that enhance the health services provided, enabling the creation of ties that result in a new organization of the family core, thus making psychosocial rehabilitation and social reintegration easier. ${ }^{15}$ In that sense, we can highlight the need for actions that contribute to the improvement of ties between professionals, relatives and users, and the need for health services that are embracing areas, able to enhance the social support network of drug addicts.

\section{CONCLUSIONS}

After understanding the perception of user' relatives about actions carried out by the family in the search for social reintegration, it was possible to observe that they feel co-responsible for treatment success. Relatives try to guide the user in the search for a new path as way to set them free from drug addiction.

It is clear that families play a key role in the life of the crack-addicted relative, especially during adolescence, since the individual experiences a period that is full of changes and needs to feel supported in any difficult situation, in this case, entering in the context of drugs. In addition, we can highlight that families need to be prepared to deal with situations of addiction. It is essential that families be alongside users, searching for strategies to help them, giving them emotional support through love and advice, as well as religious support, which appeared to be very effective in this study.

After showing actions developed by relatives that contribute to the social reintegration of their relative, this study paves the way to research on other issues. Are the actions taken by families in line with the expectations of the crack addict? What is the limit between the support based on crack addicts' needs and actions taken by families?

Therefore, we suggest that new studies be carried out, aiming to better understand the different approaches to crack users and other family members, in a way that actions taken and experiences be evaluated. Broadening this discussion will enable health professionals to develop strategies that are more suitable to the reality experienced by families in this context.

\section{REFERENCES}

1. Gabatz RIB, Johann M, Terra MG, Padoin SMM, Silva AA, Brum JL. Percepção do usuário sobre a droga em sua vida. Esc Anna Nery. 2013 Jul-Set; 17(3):520-5.

2. Pinho LB, Oliveira IR, Gonzales RIC, Harter J. Consumo de crack: repercusiones en la estrutura y en la dinámica de las relaciones familiares. Enferm Glob. 2012 Ene; (25):139-49.

3. Passos FP, Aires S. Reinserção social de portadores de sofrimento psíquico: o olhar de usuários de um Centro de Atenção Psicossocial. Physis. 2013; 23(1):13-31.

4. Branco FMFC, Sousa MNP, Brito NCC, Rocha VLPO, Medeiros JM, Junior FJGS, et al. Compulsão, criminalidade, destruição e perdas: o significado do crack para os usuários. Enferm Foco. 2012;3(4):17477.

5. Siqueira DF, Moreschi C, Pozzobon L, Vedoin PC, Walter RR, Sá RGC. Adolescente usuário de crack: relato de experiência. Rev Enferm UFSM. 2012 MaiAgo; 2(2):456-63.

6. Siqueira DF, Moreschi C, Backes DS, Lunardi VL, Filho WDL, Dalcin CB. Repercussões do uso de crack no cotidiano familiar. Cogitare Enferm. 2012 Abr-Jun; 17(2):248-54.

7. Júnior $A B$, Schneider JF. Dependência do crack: repercussões para o usuário e sua família. Rev Saúde Desenvolv. 2012 Jul-Dez; 1(2):60-79.

8. Spagnuolo RS, Juliani CMCM, Spiri WC, Bocchi SCM, Martins STF. O enfermeiro e a estratégia saúde da família: desafios em coordenar a equipe multiprofissional. Cienc Cuid Saúde. 2012 Abr-Jun; 11(2):226-34

9. Bardin L. Análise de conteúdo. $4^{\mathrm{a}}$ ed. Lisboa (PT): Edições; 2009.

10. Ministério da Saúde (BR). Conselho Nacional de Saúde. Resolução 196, de 10 de outubro de 1996: diretrizes e normas regulamentadoras de pesquisa envolvendo seres humanos. Brasília (DF): MS; 1996. 
11. Backes DS, Backes MS, Medeiros HMF, Siqueira DF, Pereira SB, Dalcin CB, et al. Oficinas de espiritualidade: alternativa de cuidado para o tratamento integral de dependentes químicos. Rev Esc Enferm USP. 2012, 46(5):1254-9.

12. Law I. Discrimination. In: Ritzer G, editor. Blackwell encyclopedia of sociology. Oxford (UK): Blackwell; 2007. p.1182-4.

13. Carvalho FRM, Brusamarello T, Guimarães AN, Paes MR, Maftum MA. Causes of relapse and search for treatment reported by drug users in a rehabilitation unit. Colomb Med. 2011; 42(Supl 1): 57-62.

14. Oliveira MC, Leite SMS. Percepções da família do dependente químico sobre a drogadição. Boletim de Enfermagem da Universidade Tuiuti do Paraná. 2010; 4(1):70-83.

15. Mielke FB, Kohlrausch E, Olschowsky A, Schneider JF. A inclusão da família na atenção psicossocial: uma reflexão. Rev Eletr Enf [online]. 2010 [acesso 2014 Fev 24]; 12(4):761-5. Disponível em: http:// www.revistas.ufg.br/index.php/fen/article/ view/6812

16. Reis HFT, Moreira TO. O crack no contexto familiar: uma abordagem fenomenológica. Texto Contexto Enferm [online]. 2013. [acesso 2014 Jun 01]; 22(4):111523. Disponível em: http://www.scielo.br/scielo.ph p?pid=S010407072013000400030\&script $=$ sci_arttext

17. Ross L. Spiritual care in nursing: an overview of research to date. J Clin Nurs. 2006; 15(7):852-62.

18. Silva PA, Silva MRS, Luz GS. Interações protetoras em famílias de alcoolistas: bases para o trabalho de enfermagem. Rev Enferm UERJ. 2012 Abr-Jun; 20(2):191-6.

19. Mombelli MA, Marcon SS, Costa JB. Caracterização das internações psiquiátricas para desintoxicação de adolescentes dependentes químicos. Rev Bras Enferm. 2010 Set-Out; 63(5):735-40.

20. Brazil. Secretaria Nacional de Políticas sobre Drogas. Relatório brasileiro sobre drogas / IME USP. Brasília (DF): SENAD; 2009. 